\title{
Cloning and functional analysis of a phosphopantetheinyl transferase superfamily gene associated with jadomycin biosynthesis in Streptomyces venezuelae ISP5230
}

\author{
Liru Wang, Jennifer McVey† and Leo C. Vining
}

Author for correspondence: Leo C. Vining. Tel: +1 902494 2040. Fax: +1 9024943736. e-mail: leo.vining@dal.ca

Department of Biology, Dalhousie University, Halifax, Nova Scotia, Canada B3H 4J1
Sequence analysis of a Xhol/Sacl fragment of chromosomal DNA downstream of jadL in the Streptomyces venezuelae ISP5230 gene cluster for jadomycin biosynthesis detected a partial ORF similar in its deduced amino acid sequence to the hetl product involved in synthesizing a regulator of heterocyst spacing in Anabaena. By probing a phage library of $S$. venezuelae DNA with the $X$ Xol/Sacl fragment, the authors identified and isolated a hybridizing clone. The nucleotide sequence of its DNA contained three complete ORFs (jadM, $N$ and $X$ ) and one incomplete ORF (jadO). The jadM ORF lay immediately downstream of, and partially overlapped, jadL. It contained 786 nucleotides encoding an amino acid sequence like those of enzymes in the phosphopantetheinyl transferase family. The jadN ORF contained 1794 nucleotides and encoded an amino acid sequence resembling acyl-CoA decarboxylases, thus suggesting a role in polyketide condensation reactions. The jadX ORF was not identified, but the partial jadO showed marked similarities in its deduced amino acid sequence to NDP-hexose-2,3-dehydratases, indicating a role in forming the sugar component of jadomycin B. Expression of jadM in Escherichia coli and examination of the product by SDS-PAGE established that the ORF encoded a 29.1 kDa protein, corresponding in size to the 262 amino acid polypeptide deduced from the jadM sequence. Evidence from a Northern hybridization indicated that jadM expression is correlated with jadomycin B synthesis. Cultures of $S$. venezuelae ISP5230 disrupted in jadM produced only 2-5\% of the wild-type titre of jadomycin B, but grew well and produced chloramphenicol normally. The authors conclude that jadM encodes a holo-ACP synthase needed primarily for jadomycin B biosynthesis.

Keywords: phosphopantetheinyl transferase gene, jad genes, polyketide antibiotic, acyl carrier protein synthase

\section{INTRODUCTION}

Polyketide synthases (PKSs) direct head-to-tail assembly of acyl precursors into intermediates that can then be processed to form a broad range of final products. The PKSs fall into two organizational groups: type I are multifunctional proteins whereas type II are multi- enzyme complexes. Genes for PKSs have been cloned and characterized from numerous bacteria, fungi and plants (Hopwood \& Sherman, 1990; Hopwood, 1997). The actinomycete Streptomyces venezuelae ISP5230 produces, in addition to chloramphenicol, a second antibiotic, jadomycin B (Doull et al., 1993, 1994), deduced from its chemical structure and the pattern of

† Present address: Department of Medicine, McMaster University, Hamilton, Ontario, Canada.

Abbreviations: ACP, acyl carrier protein; ACPS, holo-acyl carrier protein synthase; act, actinorhodin biosynthesis gene; ArCP, aryl carrier protein; CLF, chainlength factor; $\mathrm{cml}$, chloramphenicol biosynthesis gene; fren, frenolicin biosynthesis gene; gra, granaticin biosynthesis gene; jad, jadomycin biosynthesis gene; KS, ketosynthase; NRPS, non-ribosomal peptide synthetase; PCP, peptidyl carrier protein; PKS, polyketide synthase; Ppan, phosphopantetheine; PPTase, phosphopantetheinyl transferase.

The GenBank accession numbers for the jadM and jadNOX sequences reported in this paper are AF222693 and AY026363, respectively. 
its labelling by $\left[{ }^{13} \mathrm{C}\right]$ acetate to be a member of the polyketide family (S. Ayer, personal communication). Molecular genetic evidence has confirmed the structure assignment (Han et al., 1994; Yang et al., 1995, 1996) and established that jadomycin is derived from a decapolyketide generated by an iterative type-II PKS complex encoded by a chromosomal gene cluster (Meurer et al., 1997; Kulowski et al., 1999). A gene encoding a biotin-dependent acyl-CoA carboxylase potentially able to synthesize the malonyl-CoA needed to supply the C-2 extender units for jadomycin biosynthesis has been identified within the jad gene cluster (Han et al., 2000).

The polyketide family of secondary metabolites shares a general biosynthetic mechanism with the fatty acids of primary metabolism. The carbon skeletons are formed by sequential condensation of activated low-molecularmass acids, such as acetate, propionate and butyrate. The PKS condensation reaction is similar to that used by the fatty acid synthases (FAS) found in all organisms where fatty acids are required for the biosynthesis of lipids (Hopwood, 1997). Both PKS and FAS enzyme complexes require post-translational modification of their constituent acyl carrier proteins to become catalytically active. The inactive apo-proteins are converted to active holo-enzymes by esterifying a specific serine hydroxyl with the 4'-phosphopantetheine prosthetic group of coenzyme A (Lambalot et al., 1996). Genes for the phosphopantetheinyl transferases of fatty acid synthase (ACPS) and enterobactin synthetase (EntD) in E. coli have been identified (Lambalot et al., 1996), as has the gene for Sfp, responsible for activating surfactin synthetase in Bacillus subtilis (Quadri et al., 1998a).

The jad cluster of genes for jadomycin production in $S$. venezuelae ISP5230 is made up of a core group, jadABCDE, encoding the PKS that assembles the parent polyketide (Han et al., 1994) and auxiliary genes encoding supplementary enzymes with tailoring (Yang et al., 1996) or regulatory functions (Yang et al., 1995). Among the tailoring group are jadE, encoding an oxidoreductase that reduces the C-10 ketone of the incipient angucycline ring system in jadomycins (Kulowski et al., 1999), and jadF, which encodes another oxidoreductase that opens the angucycline $\mathrm{B}$ ring to facilitate insertion of isoleucine. Less clearly in the tailoring group is $j a d J$, which encodes an enzyme complex for carboxylating acetyl-CoA to malonyl-CoA and might be expected to serve a general metabolic purpose. However, the role of the gene in S. venezuelae appears to be linked to extension of the polyketide chain used for jadomycin B biosynthesis (Han et al., 2000). Here, we report evidence that another gene, jadM, located unambiguously in the jad cluster, encodes a phosphopantetheinyl transferase that is functionally associated with biosynthesis of the polyketide-derived antibiotic.

\section{METHODS}

Bacterial strains, plasmids and vectors. These are listed in Table 1.
Culture conditions. E. coli strains for plasmid isolation were grown as described by Sambrook et al. (1989). For phage DNA isolation, the protocol of Leder et al. (1977) was used. Jadomycin B was produced in galactose-isoleucine medium (Doull et al., 1994), but with isoleucine doubled to $78 \mathrm{mg} \mathrm{ml}^{-1}$ (giving Gal2I medium). Recombinant E. coli DH5 $\alpha$ strains were grown in LB medium containing appropriate antibiotics (Sambrook et al., 1989). To isolate genomic DNA, S. venezuelae strains were grown in MYM medium (Stuttard, 1982) at $30^{\circ} \mathrm{C}$ for $24 \mathrm{~h}$ on a rotary shaker (220 r.p.m.).

DNA manipulation and transformation. Plasmid DNA was isolated from E. coli by the alkaline lysis method (Sambrook et al., 1989). Bacteriophage $\lambda$ DNA was purified essentially as reported by Yamamoto et al. (1970). Genomic DNA was isolated as described by Hopwood et al. (1985). T4 DNA ligase and restriction enzymes were used as recommended by the suppliers. Competent cells of E. coli strains were prepared and transformed by the procedures of Sambrook et al. (1989). For conjugal transfer of plasmids from E. coli to streptomycetes, the protocol of Mazodier et al. (1989) was followed.

Cloning and sequencing of jadM. A $0.55 \mathrm{~kb}$ Xhol $/ \mathrm{SacI}$ fragment of jadM was obtained from a segment of $S$. venezuelae ISP5230 genomic DNA cloned in Lambda LH7 (Han et al., 1994) and subcloned in pBluescript II SK $(+)$ as pJV104 (McVey, 1998). The plasmid insert, labelled with ${ }^{32} \mathrm{P}$, was used to probe a genomic library prepared in Lambda GEM-11 from a partial Sau3AI digest of S. venezuelae ISP5230 (Facey, 1994) plated on LB agar in three $9 \mathrm{~cm}$ diameter Petri dishes, and incubated overnight to give approximately $10^{6}$ plaques. Hybridization (Sambrook et al., 1989) yielded eight labelled clones (Lambda LW1-LW8), from which DNA was extracted, digested with XhoI and probed by Southern hybridization with the $0.55 \mathrm{~kb} X h o \mathrm{I} / \mathrm{SacI}$ fragment from the plasmid pJV104. A $7 \cdot 0 \mathrm{~kb}$ labelled fragment was detected in DNA from six of the eight clones. This fragment from LW3 was inserted in the XhoI site of pBluescript II SK $(+)$ to obtain the plasmid pJV401. From pJV401, a $3.3 \mathrm{~kb}$ XhoI/KpnI fragment containing $j a d M$ was subcloned in pBluescript II $\mathrm{SK}(+)$ to give pJV402. Nested overlapping deletions were introduced into the pJV402 insert with an ExoIII/S1 deletion kit (MBI Fermentas) and the cloned DNA was sequenced (GenBank accession numbers AF222693 and AY026363) by the dideoxynuceotide chain-termination method (Sanger et al., 1977).

Sequence analysis and disruption. The sequenced pJV402 insert was examined with ORF Finder (NCBI) and FramePlot 2.3 (Ishikawa \& Hotta, 1999) to detect ORFs. BLASTX was used with individual ORF sequences to query GenBank nucleic acid and protein databases. Sequences were aligned and their relatedness was assessed with CLUSTAL w (Thompson et al., 1994). The preferred target for insertional inactivation was an NruI site $85 \mathrm{bp}$ downstream of the jadM start codon. However, this site was only $210 \mathrm{bp}$ from the Xhol end of the cloned fragment, so to increase opportunities for double crossovers when the plasmid was introduced into $S$. venezuelae, the $3.4 \mathrm{~kb} X h o \mathrm{I} / K p n \mathrm{I}$ chromosomal sequence cloned in pJV402 was extended at the $\mathrm{XhoI}$ end by ligation to a $1.3 \mathrm{~kb} \mathrm{NruI}(E c o R V) / X h o I$ fragment of pJV405 that contained $S$. venezuelae DNA adjoining jadM. The pJV405 insert had initially been subcloned in pBluescript II $\mathrm{SK}(+)$ as a $4.0 \mathrm{~kb}$ SacI fragment from Lambda LH7. One of the products (pJV404A) was digested with NruI and XhoI, then subcloned as a $1.3 \mathrm{~kb}$ fragment between the EcoRV and XhoI sites of pBluescript II SK $(+)$ to give pJV405. Digestion of $\mathrm{pJV} 405$ with $\mathrm{XhoI} / K p n \mathrm{I}$ and ligation with the $3.4 \mathrm{~kb}$ Xhol $/ K p n \mathrm{I}$ 
Table 1. Bacterial strains, plasmids and phages

\begin{tabular}{|c|c|c|}
\hline $\begin{array}{l}\text { Strain, plasmid } \\
\text { or phage }\end{array}$ & Genotype/phenotype & Source/reference \\
\hline \multicolumn{3}{|l|}{ Streptomyces venezuelae } \\
\hline ISP5230 & Wild-type, jadomycin B producer & Stuttard (1982) \\
\hline VS1075 & ISP5230 with $j a d M$ disrupted by DNA conferring $\mathrm{Am}^{\mathrm{R}}$ & This study \\
\hline VS1076 & Same as VS1075 but with $\mathrm{Am}^{\mathrm{R}}$ in opposite orientation & This study \\
\hline \multicolumn{3}{|l|}{ Escherichia coli } \\
\hline BL 21(DE3) & $\mathrm{F}^{-}$ompT hsdSB $\left(\mathrm{r}_{\mathrm{B}}^{-}, \mathrm{m}_{\mathrm{B}}^{-}\right)$gal dcm & Novagen \\
\hline DH $5 \alpha \mathrm{F}^{\prime} \mathrm{IQ}$ & $\begin{array}{l}\mathrm{F}^{\prime} \alpha 80 \text { dlacZ }(\operatorname{lac} Z Y A-\arg F) \mathrm{U} 169 \text { deoR recA1 endA1 hsdR17 } \\
\left(\mathrm{r}_{\mathrm{k}}^{-}, \mathrm{m}_{\mathrm{k}}^{-}\right) \text {phoA supE11 } \lambda^{-} \text {thi-1 gyrA96 relA1 } / \mathrm{F}^{\prime} \text { proAB } \\
\text { lac }{ }^{+} \mathrm{Z} \Delta \mathrm{M} 15 \text { zzf::Tn5}\left[\mathrm{Km}^{\mathrm{r}}\right]\end{array}$ & Gibco BRL \\
\hline ET 12567(pUZ8002) & ET12567 containing pUZ8002 & $\begin{array}{l}\text { M. Paget, John Innes Centre, } \\
\text { Norwich, UK }\end{array}$ \\
\hline LE 392 & $\Delta($ lacIZY $) 6$ galK2 galT22 metBI trpR55 $\lambda^{-}$ & Maniatis et al. (1982) \\
\hline \multicolumn{3}{|l|}{ Plasmids } \\
\hline pBluescript II & $\begin{array}{l}\text { Phagemid derivative of pUC18 with } \mathrm{SK}+\text { and } \mathrm{KS}+, \mathrm{f} 1 \text { ori, and } \\
\text { primer-binding sites for } \mathrm{T} 3 \text { and } \mathrm{T} 7\end{array}$ & Stratagene \\
\hline pET $21+$ & amp, primer-binding sites for $\mathrm{T} 7$ promoter and terminator & Novagen \\
\hline pHJL400 & tsr amp lac Z, bifunctional & Larson \& Hershberger (1986) \\
\hline pUZ8002 & $\mathrm{cml} \mathrm{km} \mathrm{tra}$ & M. Paget \\
\hline pJV104 & $\begin{array}{l}\text { pBluescript II SK }(+) \text { containing } 5^{\prime} \text {-region of } j a d M \text { in a } 0.55 \mathrm{~kb} \\
\text { XhoI/SacI insert sub-cloned from Lambda LH7 }\end{array}$ & McVey (1998) \\
\hline pJV105 & pHJL400 with 4.0 kb SacI fragment from Lambda LH7 & McVey (1998) \\
\hline pJV225 & $\begin{array}{l}\text { pBluescript II SK }(+) \text { containing } \mathrm{Am}^{\mathrm{R}} \text { gene flanked by multiple } \\
\text { cloning sites }\end{array}$ & Chang (1999) \\
\hline pJV326 & $\mathrm{pHJL} 400$ containing $0.76 \mathrm{~kb}$ Pst $\mathrm{I}$ insert with oriT, bifunctional & $\begin{array}{l}\text { J. Y. He (personal } \\
\text { communication) }\end{array}$ \\
\hline pJV401 & pBluescript II SK(+) with $6.6 \mathrm{~kb}$ XhoI insert from Lambda LW3 & This study \\
\hline pJV402 & $\begin{array}{l}\text { pBluescript II SK }(+) \text { with } 3.4 \mathrm{~kb} X h o I / K p n I \text { insert containing } 5^{\prime}- \\
\text { region of } j a d M \text { and downstream genes }\end{array}$ & This study \\
\hline pJV403 & $\begin{array}{l}\text { pBluescript II SK(+) with } 3 \cdot 0 \mathrm{~kb} E c o \mathrm{RV} / \mathrm{XboI} \text { insert containing } \\
5^{\prime} \text {-region of } j a d M \text { and downstream genes }\end{array}$ & This study \\
\hline $\mathrm{pJV} 404 \mathrm{~A} / \mathrm{B}$ & $\begin{array}{l}\text { pBluescript II SK }(+) \text { with } 4.0 \mathrm{~kb} \text { SacI fragment from pJV105 (two } \\
\text { orientations) }\end{array}$ & This study \\
\hline pJV405 & $\begin{array}{l}\text { pBluescript II SK(+) with } 1.3 \mathrm{~kb} \mathrm{NruI} / \text { Xhol fragment from } \\
\text { pJV404A in its EcoRV site }\end{array}$ & This study \\
\hline pJV406 & $\begin{array}{l}\text { pBluescript II SK(+) with } 4.7 \mathrm{~kb} \mathrm{NruI} / \mathrm{KpnI} \text { fragment (ligated } \\
\text { pJV402 and pJV405 inserts) in its EcoRV site }\end{array}$ & This study \\
\hline $\mathrm{pJV} 407 \mathrm{~A} / \mathrm{B}$ & 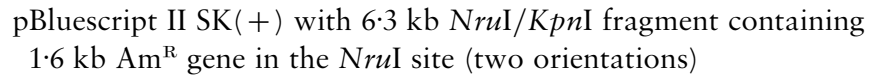 & This study \\
\hline $\mathrm{pJV408A/B}$ & $\begin{array}{l}\text { pJV326 with blunted } 5 \cdot 6 \mathrm{~kb} \text { EcoRI/EcoRV fragment from } \\
\text { pJV407A/B in its blunted BamHI site (two orientations) }\end{array}$ & This study \\
\hline pJV409 & $\begin{array}{l}\text { pET-21 }(+) \text { with a blunt-ended } 1 \cdot 0 \mathrm{~kb} \text { XhoI/PvuII fragment from } \\
\text { pJV402 in its blunted Bam HI site }\end{array}$ & This study \\
\hline \multicolumn{3}{|l|}{ Phages } \\
\hline Lambda LH7 & Lambda GEM-11 with a $14 \mathrm{~kb}$ insert of S. venezuelae DNA & Han et al. (1994) \\
\hline Lambda LW3 & $\begin{array}{l}\text { Lambda GEM-11 with an } 11.5 \mathrm{~kb} \text { insert of S. venezuelae DNA } \\
\text { hybridizing with pJV104 }\end{array}$ & This study \\
\hline Lambda gene bank & $\begin{array}{l}\text { Lambda GEM-11 with } 9 \cdot 0-23 \cdot 0 \mathrm{~kb} \text { inserts of S. venezuelae } \\
\text { genomic DNA }\end{array}$ & Facey (1994) \\
\hline
\end{tabular}

fragment from pJV402 gave pJV406 (Fig. 1a). Digestion of pJV406 with NruI, dephosphorylation with calf intestinal alkaline phosphatase and ligation with the $1.6 \mathrm{~kb}$ EcoRV cassette containing apr (retrieved from pJV225) yielded constructs with $a p r$ in alternative transcriptional orientations (opposite to jadM in pJV407A; similar in pJV407B). Linearizing $\mathrm{pJV} 407 \mathrm{~A} / \mathrm{B}$ with EcoRI/EcoRV, blunting the $5.6 \mathrm{~kb}$ linear products with S1 nuclease and ligation to the promiscuous vector pJV326 linearized with BamHI and blunted with S1 nuclease, gave pJV408A/B (with the apr 
(a)

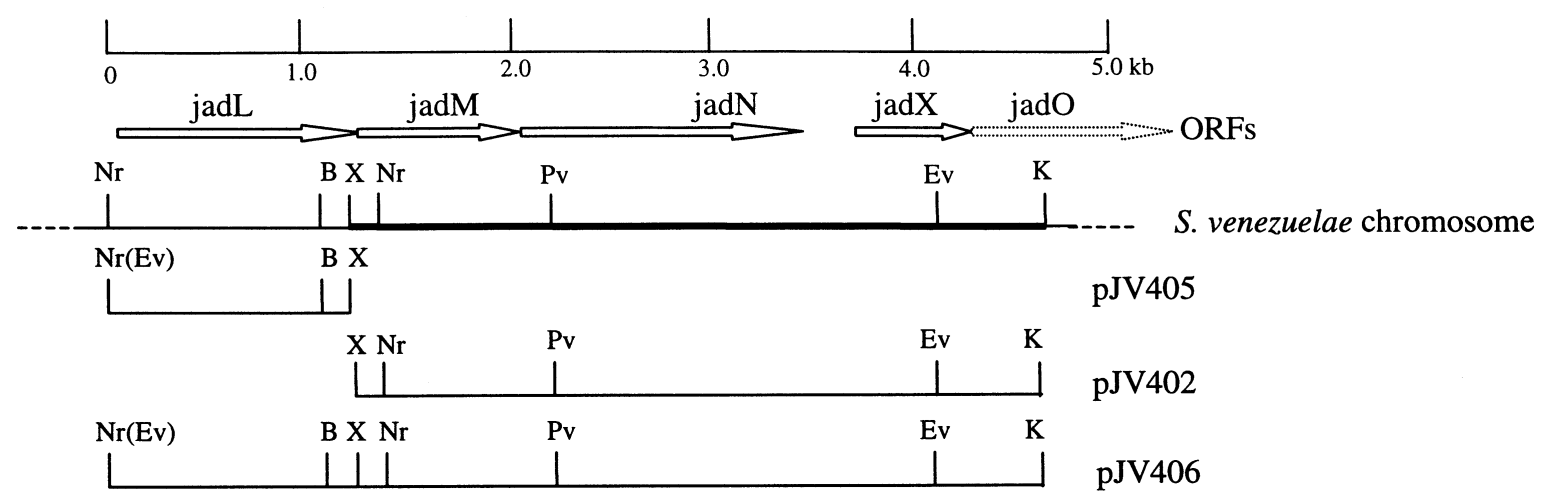

(b)
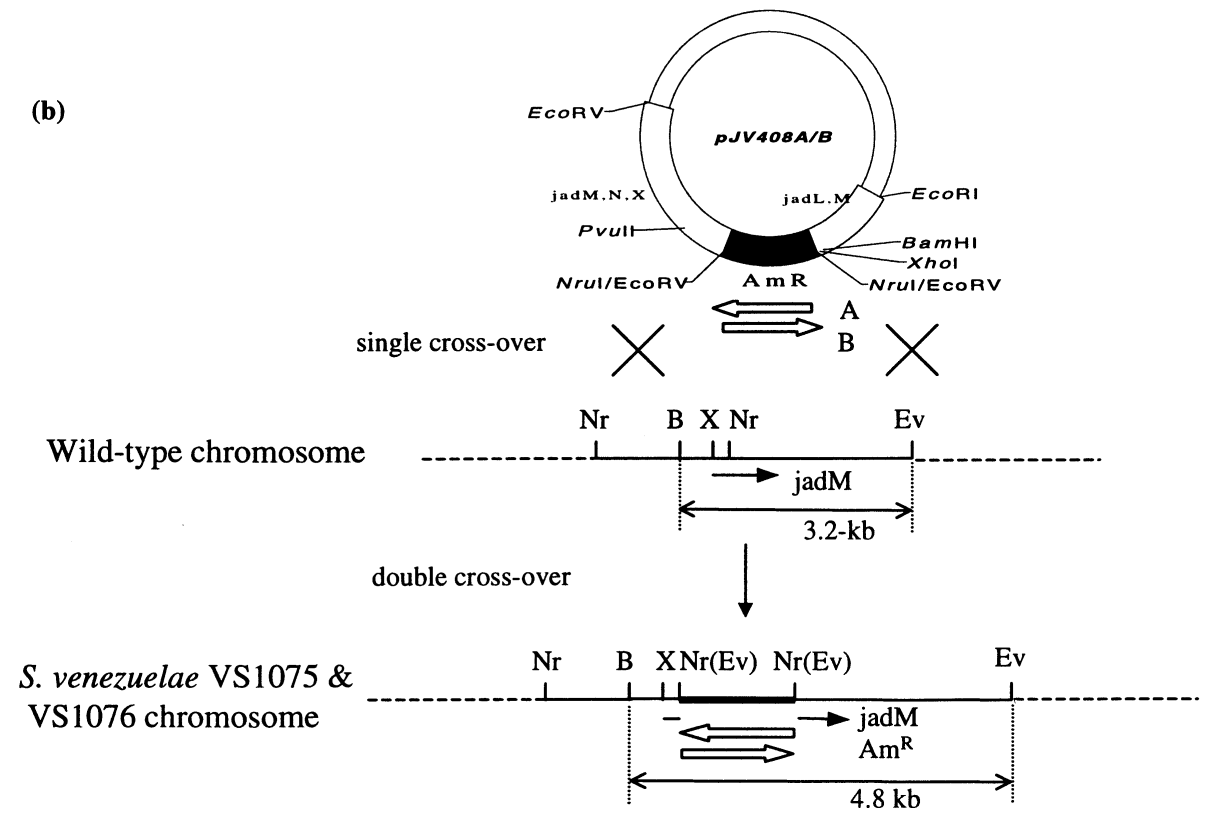

Fig. 1. (a) Restriction map of the $4.6 \mathrm{~kb}$ fragment of $S$. venezuelae ISP5230 genomic DNA subcloned from the recombinant $\lambda$ vectors LH7 (Han et al., 1994) and LW3 (see text). Numbers below the line at the top indicate distances in $\mathrm{kb}$. The $3.4 \mathrm{~kb}$ region retrieved from $\lambda \mathrm{LW} 3$ and subcloned in pBluescript II SK(+) is shown as a thickened line. Arrows above the restriction map show the locations and orientations of ORFs (jadM, jadN, jadX, jadO) in the jad cluster. Restriction sites in the inserts of plasmids pJV402, pJV405 and pJV406 are aligned below the chromosomal map. Abbreviations: B, BamHI; Ev, EcoRV; K, Kpnl; Nr, Nrul; Pv, Pvull; X, Xhol; Am ${ }^{\mathrm{R}}$ apramycin resistance. (b) Disruption of jadM: a cassette containing the apramycin-resistance gene in alternative orientations (A or B) was inserted into the Nrul site within jadM cloned in pJV408. Introduction of the plasmids into S. venezuelae gave strains (VS1075 and VS1076) with double crossovers selected for their $\mathrm{Am}^{R}$ Thio ${ }^{S}$ phenotype.

fragment in alternative orientations). The constructs were transferred conjugally from E. coli to $S$. venezuelae ISP5230 (Fig. 1b).

Hybridization. Procedures described by Hopwood et al. (1985) and Sambrook et al. (1989) were used to screen an $S$. venezuelae ISP5230 genomic DNA library in Lambda GEM-11 (Facey, 1994). Phage propagated in E. coli LE392 was suspended in $2.5 \mathrm{ml}$ top agar and spread on LB agar in $9 \mathrm{~cm}$ Petri plates to form plaques. Plaque DNA was adsorbed on a nylon membrane, denatured, neutralized and bound to the nylon $\left(80^{\circ} \mathrm{C}\right.$ for $2 \mathrm{~h}$ ) before incubation at $65^{\circ} \mathrm{C}$ in hybridization solution (Sambrook et al., 1989) with a ${ }^{32} \mathrm{P}-$ labelled probe. The membrane was washed twice by agitation with $1 \times \mathrm{SSC} / 0 \cdot 1 \% \mathrm{SDS}$ at room temperature and once with $0 \cdot 1 \times$ SSC $/ 0 \cdot 1 \%$ SDS at $65{ }^{\circ} \mathrm{C}$ for $1 \mathrm{~h}$. It was then exposed to a Bio-Rad CS phosphor-imaging screen for approximately
$24 \mathrm{~h}$. Hybridization signals on the screen were detected using the GS-525 Molecular Imaging system (Bio-Rad). In Southern hybridizations, plasmid DNA digested with restriction enzymes was fractionated by agarose gel electrophoresis, transferred to a nylon membrane and processed as above.

Jadomycin production and analysis. Cultures of $S$. venezuelae ISP5230 were grown from a vegetative inoculum obtained by incubating a spore suspension $(20 \mu \mathrm{l})$ in $25 \mathrm{ml} \mathrm{MYM} \mathrm{medium}$ (Stuttard, 1982) in a $125 \mathrm{ml}$ Erlenmeyer flask on a rotary shaker for $24 \mathrm{~h}$ at $30^{\circ} \mathrm{C}$. Portions $(1 \mathrm{ml})$ of this culture were used to inoculate $25 \mathrm{ml} \mathrm{Gal2I}$ medium in $125 \mathrm{ml}$ Erlenmeyer flasks. The Gal2I cultures, after incubation as above for $6 \mathrm{~h}$, were supplemented with $0.75 \mathrm{ml}$ of absolute ethanol and incubation was resumed for $48 \mathrm{~h}$. Filtered broths were extracted with ethyl acetate and assayed by HPLC using Beckman System Gold equipment and software. Culture 
extracts $(20 \mu \mathrm{l})$ in methanol were injected on a $\mathrm{C}_{18}$ reversephase silica column $(50 \times 4.6 \mathrm{~mm})$ and eluted at a flow rate of $1 \mathrm{ml} \mathrm{min}{ }^{-1}$ with a linear gradient from $100 \%$ solvent A (acetonitrile/water, 1:1) to 25, 50, 100 and $0 \%$ solvent $\mathrm{B}$ (100\% acetonitrile) programmed to change after $3,6 \cdot 5,7 \cdot 5$ and $10 \mathrm{~min}$, respectively. Both solvents contained $0 \cdot 1 \%(\mathrm{v} / \mathrm{v})$ trifluoroacetic acid. Jadomycins in the eluate were monitored at $313 \mathrm{~nm}$; jadomycin $\mathrm{B}$ had a retention time of $7 \cdot 5 \mathrm{~min}$.

Northern hybridization. RNA was isolated from Gal2I cultures of S. venezuelae ISP5230 with the modified Kirby mix, followed by phenol/chloroform extraction and DNase I treatment (Kieser et al., 2000). It was fractionated and adsorbed on nylon membranes (GeneScreen \& GeneScreen Plus, NEN Life Science) by the method of Sambrook et al. (1989). Northern hybridization followed NEN's protocol for their products.

Bioassay of chloramphenicol. The method was modified from that of Doull et al. (1986). Spores of an S. venezuelae strain spread evenly on MYM agar in a $9 \mathrm{~cm}$ Petri plate were incubated at $30{ }^{\circ} \mathrm{C}$ for $48-72 \mathrm{~h}$. Plugs were removed aseptically with a cork borer, placed equidistantly on MYM agar in $9 \mathrm{~cm}$ Petri plates and incubated at $30{ }^{\circ} \mathrm{C}$ for $12-14 \mathrm{~h}$. They were then overlaid ( $2.5 \mathrm{ml}$ per plate) with soft GNY agar (Malik \& Vining, 1970) seeded with $1.0 \%$ (v/v) of a Micrococcus luteus culture grown overnight in GNY liquid medium. The overlaid plates were incubated overnight and the plugs were examined for zones of inhibition.

Expression of jadM in E. coli. A $1.0 \mathrm{~kb}$ Xhol/PvuII fragment containing jadM was retrieved from pJV406 (see Fig. 1a), blunt-ended with S1 nuclease and ligated (T4 DNA ligase) to pET-21 $(+)$, also linearized with Bam HI and blunt-ended with S1 nuclease. Transforming E. coli BL21(DE3) with the ligation mixture yielded a colony from which pJV409 was isolated. Cultures of the transformant and E. coli BL21(DE3) harbouring pET-21 $(+)$ were grown to late-exponential phase in LB medium; the T7 polymerase promoter in $\mathrm{pET}-21(+)$ was induced with isopropylthio $\beta$-galactopyranoside $(1 \mathrm{mM}$ final concentration) and cells harvested by centrifugation were resuspended in gel loading buffer $(62.5 \mathrm{mM}$ Tris/ $\mathrm{HCl}, \mathrm{pH} 6.8$; $2 \%, \mathrm{w} / \mathrm{v}, \mathrm{SDS} ; 5 \%, \mathrm{v} / \mathrm{v}, 2$-mercaptoethanol; $10 \%, \mathrm{v} / \mathrm{v}$, glycerol; $0.025 \%$ bromphenol blue), lysed by heating at $100{ }^{\circ} \mathrm{C}$ for 3-5 min and analysed by SDS-PAGE (Laemmli, 1970). Total proteins electrophoresed on a $4 \%(\mathrm{w} / \mathrm{v})$ polyacrylamide stacking gel and a $15 \%(\mathrm{w} / \mathrm{v})$ separating gel were visualized by staining the gel with $0 \cdot 1 \%$ Coomassie brilliant blue R-250.

\section{RESULTS}

\section{Sequence of jadM and downstream genes}

Sequencing and analysis of the $3.4 \mathrm{~kb} X h o \mathrm{I} / \mathrm{KpnI}$ insert in pJV402 detected three complete ORFs and one partial ORF (see Fig. 1a). Their $77 \cdot 3,70 \cdot 0,72 \cdot 3$ and $71 \cdot 2, \mathrm{~mol} \%$ $\mathrm{G}+\mathrm{C}$ contents were in the range expected for streptomycete genes. The putative ATG start codon of the ORF containing $j a d M$ was located 26 bp inside the $3^{\prime}$-end of the preceding ORF (jadL; McVey, 1998). A putative RBS (AAGG) for jadM could be recognized $10 \mathrm{bp}$ upstream of the start codon, and an in-frame downstream stop codon (TGA) predicted a gene of $786 \mathrm{bp}$ encoding a protein with 262 amino acids. The next ORF (containing $j a d N$ ) was oriented for transcription in the same direction as jadM, and shared two nucleotides of its ATG start codon with the jadM stop codon. The
jadN ORF was predicted to terminate 1578 bp downstream of its starting ATG. In a BLASTX search, the deduced amino acid sequence of $j a d N$ showed strong similarity to several malonyl-CoA decarboxylases and putative propionyl-CoA carboxylases. Malonyl-CoA is one of the most common chain-extender units for the biosynthesis of polyketide antibiotics in streptomycetes (Hopwood \& Sherman, 1990), and its use in the synthesis of jadomycin would be expected. Therefore jadN may function as a malonyl-CoA decarboxylase in polyketide condensation reactions. The supply of malonyl-coenzyme A needed for these reactions is potentially available as the product of another jad cluster gene, jadJ, that encodes a biotin carboxylasebiotin carboxyl carrier protein able to convert acetylCoA to malonyl-CoA (Han et al., 2000). Possibly jadN functions in conjunction with $j a d J$ to support polyketide chain extension in jadomycin biosynthesis. The third complete ORF in pJV402 ( $j a d X)$ is transcribed in the same direction as $j a d L-N$, but is separated from the $3^{\prime}$ end of $j a d N$ by $268 \mathrm{bp}$. A BLASTP search of GenBank for protein sequences resembling the deduced $j a d X$ amino acid sequence showed similarity to several proline-rich plant cell wall proteins, but the function of the gene in $S$. venezuelae is not known. Immediately downstream of jadX, and transcribed in the same direction, is the partial ORF containing a putative $j a d O$. It begins with an ATG that shares the last letter in the $j a d X$ stop codon and its deduced amino acid sequence strongly resembled several NDP-hexose 2,3-dehydratases. As jadomycin B contains a 2,6-dideoxyhexose component in addition to the aromatic jadomycin aglycone, jadO is probably involved in biosynthesis of the sugar moiety.

\section{Function of jadM}

Database searches with BLASTX showed that the deduced amino acid sequence of $j a d M$ is $36 \%$ similar and $24 \%$ identical to the 237 amino acid sequence of HetI in Anabaena PCC7120. In this cyanobacterium, hetI, het M and het $\mathrm{N}$ have been implicated in the production of an unidentified secondary metabolite regulating heterocyst spacing (Black \& Wolk, 1994). Sequence analysis indicates that HetN is an NAD $(\mathrm{P}) \mathrm{H}$-dependent enzyme similar to oxidoreductases associated with polyketide and fatty acid biosynthesis, and in addition suggests that HetM contains an ACP domain. Similarities between HetI and members (Spf, Gsp and Ent) of the phosphopantetheinyl transferase superfamily (Lambalot et al., 1996; Walsh et al., 1997; Silakowski et al., 1999) led Lambalot et al. (1996) to propose that HetI is a HetMspecific PPTase involved in synthesis of the secondary metabolic product influencing heterocyst formation. In addition to resembling the HetI sequence in Anabaena, the deduced amino acid sequence of $j a d M$ resembles the sequence of MtaA in Stigmatella aurantiaca (29\% similar and $22 \%$ identical amino acids). This protein is a PPTase activating biosynthesis of the electrontransport inhibitor myxothiazol, probably by posttranslational modification of $\mathrm{MtaB}, \mathrm{MtaG}$ and the unique combination of PKSs and nonribosomal peptide 


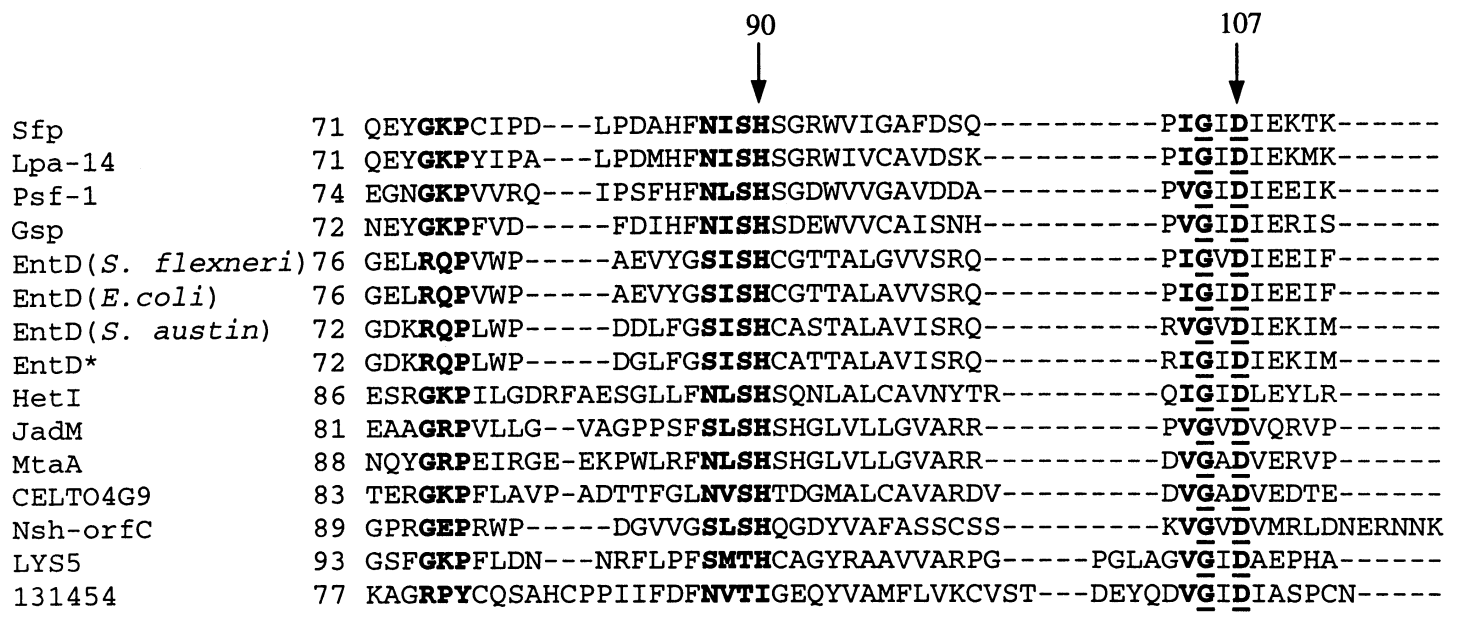

\begin{tabular}{|c|c|c|}
\hline $\mathrm{fp}$ & 113 & PIS--LEIAKRFFSKT-EYSDLLAKDKDEQTDYFYHLWSSMKESFIKQEEGKGLSLPL \\
\hline oa-14 & 113 & PGT--IDIAKRFFSPT-EYSDLQAKHPDQQTDYFYHLW̄SMKES FI $\bar{K} Q A G K G L S L P L$ \\
\hline ?sf-1 & 116 & PID--LAIAERFFSAD-EYQDLLSQPAERQEAYFFHLW̄SMKEA FI \\
\hline Gsp & 112 & EID--IKIAEQFFHEN-EYIWLQSKAQNSQVSSFFELWTTI \\
\hline $\operatorname{EntD}(S$. flexneri) & 116 & 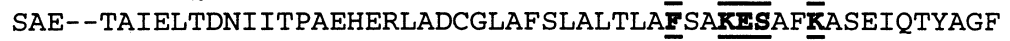 \\
\hline $\operatorname{EntD}(E . \operatorname{col} i)$ & 116 & 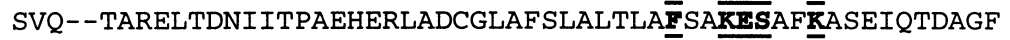 \\
\hline $\operatorname{EntD}(S$. austin) & 112 & 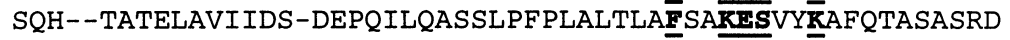 \\
\hline EntD* & 112 & 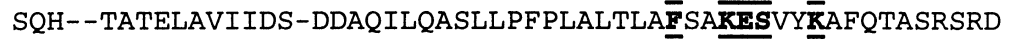 \\
\hline Het I & 132 & 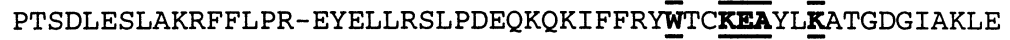 \\
\hline$a d m$ & 124 & 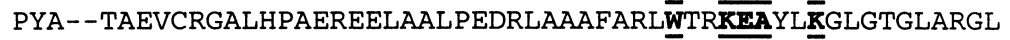 \\
\hline itaA & 133 & RRGETVEIADSFFAPA-EVASLRALPVSGQRERFFDYW̄TL $\overline{\overline{K E A} Y I \bar{K} A R G M G L S L P L}$ \\
\hline CELTO4G9 & 134 & TADEYINSMAKSASPEELRMMRSQPTEAMKMTMFYRYW̄CL $\overline{\overline{K F A} I L \overline{\mathbf{K}} A T G V G I M K D L}$ \\
\hline Nsh-orfC & 134 & 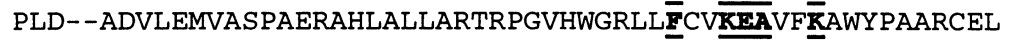 \\
\hline LYS5 & 143 & 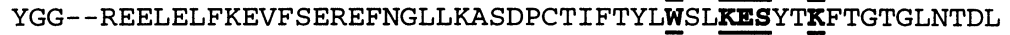 \\
\hline 131454 & 132 & PLAFEASWMEDFMSVFTPCEWKLIKSSISSIDVFFLLW̄TC $\overline{\text { KFAA } I L \bar{K} A L G I G L S G N P ~}$ \\
\hline
\end{tabular}

Fig. 2. Multiple sequence alignment with CLUSTAL W. Highly conserved amino acids are shown in bold letters; conserved sequences in the PPTase superfamily are in bold and underlined. As an aid to locating key regions, the residues at positions 90, 107 and 151 are marked with a vertical arrow. The organisms involved are: Sfp, Bacillus subtilis; Lpa-14, B. subtilis; Psf-1, B. pumilus; Gsp, B. brevis; EntD*, Salmonella typhimurium; Hetl, Anabaena PCC7120; JadM, Streptomyces venezuelae; MtaA, Stigmatella aurantiaca; CELTO4G9, Caenorhabditis elegans; Nsh-orfC, Streptomyces actuosus; LYS5, Saccharomyces cerevisiae; 131454, Schizosaccharomyces pombe.

synthetases (NRPSs) forming the biosynthetic machinery for making myxothiazol (Silakowski et al., 1999). MtaA may also be responsible for transferring Ppan to proteins involved in the biosynthesis of a variety of secondary metabolites in S. aurantiaca.

\section{Comparison of JadM with the phosphopantetheinyl transferase superfamily}

Phosphopantetheinyl transferase activity was first detected in EntD from E. coli and Spf from B. subtilis. Acyl carrier protein synthetase (ACPS), which catalyses conversion of the inactive apo-form of a fatty acid synthase complex to the functional form, was the first PPTase for which the gene was cloned and characterized. Several genes involved in peptide secretion (entD in $E$. coli, sfp in B. subtilis and gsp in Bacillus brevis) have since been identified, and their products appear to represent a new class of proteins (Borchert et al., 1994).
Through refinement of sequence alignments that indicated $12-22 \%$ similarity with the ACPS peptide sequence, a PPTase superfamily that included the Sfp/ Gsp/EntD group was identified (Lambalot et al., 1996; Gehring et al., 1997). Gsp is present in a locus required for gramicidin biosynthesis; EntD and Sfp were originally reported to activate enterobactin and surfactin synthetase, respectively, and Sfp was recently reported to modify the apo-form of heterologous recombinant proteins, including the PCP domain of Saccharomyces cerevisiae Lys2 (involved in lysine biosynthesis; Ehmann et al., 1999) and the E. coli ACP domain (Quadri et al., 1998a; Gokhale et al., 1999). Lambalot et al. (1996) identified two consensus motifs shared by PPTase family members, and further study implicated the conserved residues in enzymic reactions transferring the phosphopantetheinyl moiety of coenzyme A to the hydroxyl of conserved serines in the ACP domain of PKS and the PCP domain of NRPS (Reuter et al., 1999). 


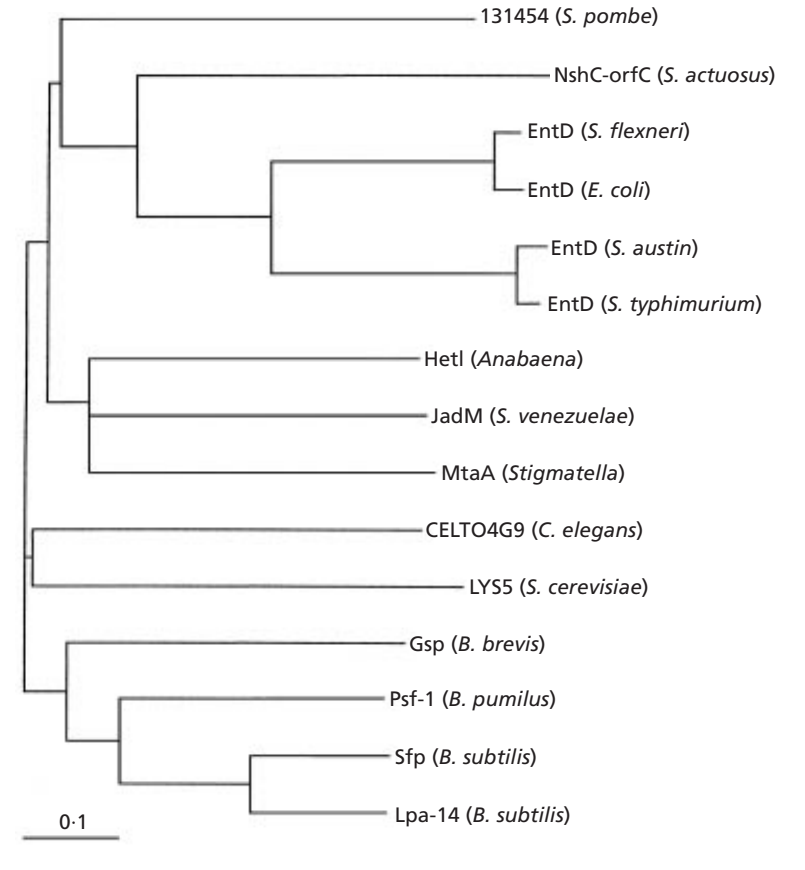

Fig. 3. Phylogenetic tree showing the relationship of the JadM sequence to the sequences of PPTase superfamily members in the GenBank database.

To determine whether JadM contained the PPTase consensus, CLUSTAL w was used to align the sequence with members of the PPTase superfamily (Fig. 2). Highly conserved amino acids in the superfamily were present in JadM, and also in some residues considered important in Sfp-type PPTases (Reuter et al., 1999). The crystal structure of Sfp enzymes indicates that the active site accommodates a magnesium ion that complexes with the pyrophosphate group in coenzyme $\mathrm{A}$, the side chains of three acidic amino acids and one water molecule (Reuter et al., 1999). These are highly conserved regions that may interact with PCP substrates. In Sfp the $\mathrm{Mg}^{2+}$ liganding residues Asp107 and Glu151 are highly conserved in every enzyme listed in Fig. 2, including JadM. The $\alpha$-phosphate of coenzyme A binds to Lys155 and His90. In JadM and all PPTases investigated, except 131454, Lys150 and His90 were highly conserved, while position 105 was invariably glycine for spatial reasons. The sequence motif Gly74-Lys75-Pro76 involved in binding the adenine base of coenzymeA was preserved in JadM, but with the Lys75 replaced by arginine. This is an acceptable substitution because Lys75 forms only hydrogen bonds and not a salt bridge with the mainchain carbonyls of Ile104, Lys155 and Gln156 (Reuter et al., 1999). A CLUSTAL $w$ alignment of the deduced amino acid sequence of $j a d M$ with the sequences of PPTases from other organisms supported assignment of the gene to the PPT ase superfamily. The phylogenetic tree in Fig. 3 indicates that JadM, HetI and MtaA have a common ancestor, and that these three genes are more closely related to one another than to other members of the family. Comparisons of the deduced amino acid se- (a)

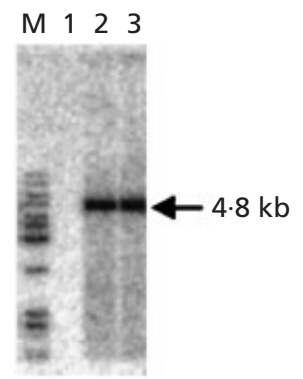

(b)

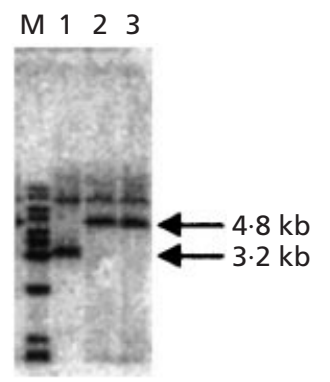

Fig. 4. Southern hybridization of genomic DNA digested with BamHI/EcoRV. Lane 1, S. venezuelae ISP5230; lane 2, VS1075; lane 3, VS1076; lane M, DNA size marker. Panel (a) probed with labelled $1.6 \mathrm{~kb} \mathrm{Am}^{\mathrm{R}}$ gene; panel (b) probed with labelled $3.2 \mathrm{~kb}$ BamHI/EcoRV fragment.

quence of $j a d M$ with database sequences are consistent with such a conclusion.

\section{Temporal expression of jadM}

Cultures of S. venezuelae ISP5230 grown in Gal2I medium for $24,48,72$, or $96 \mathrm{~h}$, either with or without ethanol supplementation at $6 \mathrm{~h}$, were assayed for jadomycin B, and total RNA extracted from the mycelium was used in Northern hybridizations. Gels from electrophoresis of $40 \mu \mathrm{g}$ RNA samples were probed with the $\left[{ }^{32} \mathrm{P}\right] \mathrm{dCTP}-\mathrm{labelled}, 3 \cdot 4 \mathrm{~kb}, \mathrm{XhoI} / \mathrm{K} p n \mathrm{I}$ insert from pJV402 containing jadM. Expression of jadM mRNA was strongest $24 \mathrm{~h}$ after ethanol supplementation, and was still detectable at $48 \mathrm{~h}$, but could not be detected at $96 \mathrm{~h}$. The jadomycin B titre was highest $48 \mathrm{~h}$ after ethanol treatment, as reported by Doull et al. (1994), and had fallen to near zero in $72 \mathrm{~h}$ cultures. At all stages of growth, neither jadomycin B nor jadM mRNA was detected in cultures not treated with ethanol.

\section{Disruption of jadM}

To avoid restriction in S. venezuelae ISP5230, plasmid constructs $\mathrm{pJV} 408 \mathrm{~A} / \mathrm{B}$ were passaged through the DNA methylation-deficient E. coli strain ET12567(pUZ8002) before being transferred from E. coli to S. venezuelae by interspecies conjugation (Mazodier et al., 1989). pUZ8002 is a large (about $70 \mathrm{~kb}$ ) plasmid carrying the tra genes that facilitate conjugational transfer of a plasmid containing the oriT sequence. Single colonies of VS1075 and VS1076 transconjugants resistant to apramycin but sensitive to thiostrepton were selected. When genomic DNA was extracted from S. venezuelae ISP5230, VS1075 and VS1076, digested with EcoRV/ BamHI, and probed by Southern hybridization with a ${ }^{32}$ P-labelled $3 \cdot 2 \mathrm{~kb}$ Bam HI/EcoRV fragment of pJV406 containing jadM, the $S$. venezuelae ISP5230 digest gave a single strong signal at $3.2 \mathrm{~kb}$, whereas VS1075 and VS1076 digests gave a comparable signal at $4.8 \mathrm{~kb}$ (Fig. 4). Use of the $1.6 \mathrm{~kb}$ apr cassette as a probe gave a single 
M pET21+ 409(-) 409(+) 1

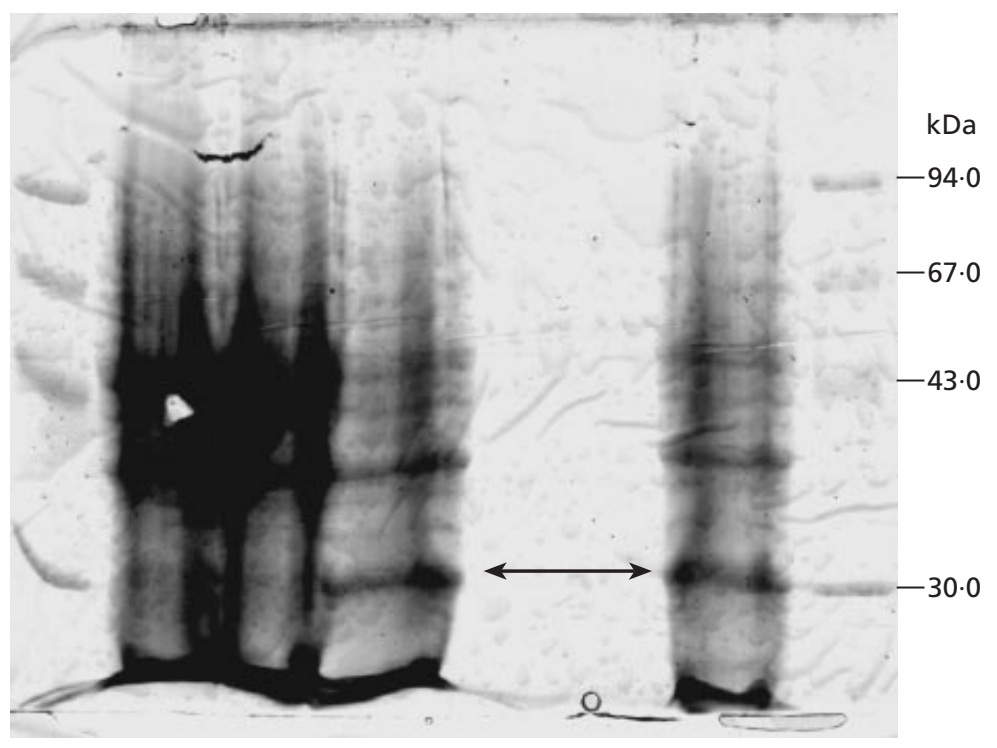

Fig. 5. Analysis of jadM expression in $E$. coli by SDS-PAGE. Lane $\mathrm{M}$, molecular markers; $\mathrm{pET}-21(+)$, E. coli BL21(DE3) transformed with $\mathrm{pE}-21(+)$ and induced with IPTG; lane $409(-)$, E. coli BL21(DE3) transformed with pJV409 without induction; lanes 409(+) 1 and $409(+)$ 2, two samples of $E$. coli BL21(DE3) transformed with pJV409 and induced with IPTG. The doubleheaded arrow points to the $29 \cdot 1 \mathrm{kDa}$ protein. strong hybridization signal at $4.8 \mathrm{~kb}$ from the disrupted strains VS1075 and VS1076, as expected for doublecrossover mutants. Cultures of VS1075 and VS1076 grew normally on minimal agar, but produced only $2-5 \%$ of the wild-type jadomycin B titre when grown in Gal2I liquid medium optimized for jadomycin B production and supplemented with ethanol. The low titre in both strains indicated that insertion of the apr cassette interfered with jadM expression, irrespective of apr orientation. A polar effect of the insertion cannot be excluded, but the $\mathrm{Am}^{\mathrm{R}}$ gene is accompanied by its promoter (Kaster et al., 1983), and the apr cassette is not known to include a terminator that would interrupt transcription in both mutants. To determine if jadM was essential for chloramphenicol biosynthesis, the disrupted and wild-type strains were bioassayed after growth on MYM agar under conditions suitable for chloramphenicol production (Doull et al., 1986). No decrease in the inhibition zone size was detected in strains VS1075 and VS1076, indicating that the jadMdisrupted mutants retained their ability to produce chloramphenicol.

\section{Expression of jadM in E. coli}

To confirm that the RBS (AAGG), ATG start codon and TGA stop codon detected in the cloned sequence correctly defined jadM, a $1.0 \mathrm{~kb}$ XhoI/PvuII pJV402 fragment expected to contain the gene (see Fig. 1a) was cloned in pET-21 $(+)$, giving pJV409. Extracts of E. coli BL21(DE3) cells harbouring pJV409 contained substantial amounts of a protein, close to $29 \cdot 1 \mathrm{kDa}$ in size (Fig. $5)$, that was absent from extracts of E. coli BL21(DE3) transformed with the pET-21 $(+)$ vector alone, and also from extracts of the transformed but uninduced $E$. coli host. These results imply that jadM supplied the RBS and start codon needed to synthesize the $29 \cdot 1 \mathrm{kDa}$ protein that was overexpressed after induction of the T7 polymerase promoter. Overall, they confirm that the jadM gene cloned from S. venezuelae ISP5230, and assigned to the PPTase superfamily by comparing the sequence of its product with database proteins, encodes a protein of the size estimated from the deduced amino acid sequence.

\section{DISCUSSION}

Although searching the GenBank database with BLASTX failed to identify E. coli ACP synthase or the Sfp/ Gsp/EntD group of PPTases as homologues of JadM, and showed only 22-24\% sequence identity between JadM and the two most closely related PPTases (HetI and MtaA), the deduced amino acid sequence of JadM contained residues highly conserved in the PPTase family; thus sequences present in the Sfp/Gsp/EntD group of PPTases were also present in the jadM product. Information now available on the crystal structure of Sfp indicates that these residues are most probably involved in interactions with the pantetheinylation substrate (Reuter et al., 1999), and suggests a similarity in reaction mechanism. We conclude that JadM contains a Ppan transferase domain and is a member of the PPTase superfamily. Its most probable function is to convert the inactive apo-enzyme form of JadC (the $j a d$ cluster ACP; Han et al., 1994) to the functional holoenzyme by transferring the 4 '-phosphopantetheinyl moiety from coenzyme A to the $\beta$-hydroxy group of the conserved serine in JadC. The newly introduced $-\mathrm{SH}$ group of the Ppan prosthetic group would act as a nucleophile in acylations by coenzyme A esters catalysed by a PKS (Lambalot et al., 1996). The severely decreased jadomycin B titre after insertional inactivation of jadM with an apr cassette indicates that the $j a d M$ product has a major role in jadomycin biosynthesis. The residual 
production in jadM disruptants might arise from the activity of a FAS pantetheinyl transferase. The preliminary evidence obtained from a Northern hybridization indicated that $j a d M$ is expressed only in cultures stressed by ethanol treatment, and that expression reaches its maximum in $24 \mathrm{~h}$, then decreases rapidly to become undetectable. This is consistent with previous results (Doull et al., 1993, 1994) showing that jadomycin B is produced by S. venezuelae ISP5230 only during a limited period after exposure to stress. Under our experimental conditions, peak expression of jadM preceded by $24 \mathrm{~h}$ the maximum jadomycin B titre, a lag suggesting that stress activation may be followed by relatively slow production and excretion of the antibiotic product. Nevertheless, the correlation between $j a d M$ transcription and jadomycin B production implies that JadM has a specific function in the pathway.

For the biosynthesis of type-II polyketide antibiotics in streptomycetes, each PKS complex must have a dedicated holo-ACP, which in turn requires a specific holoACP synthase. The latter enzymes function as integral components of the antibiotic biosynthesis pathway and differ from those that participate in fatty acid biosynthesis (Hopwood \& Sherman, 1990; Hutchinson, 1995). However, both fren and gra apo-ACPs could be phosphopantetheinylated in vitro by purified E. coli ACPS. When combined with ACP-deficient act ketosynthase and chain-length factor isolated from Streptomyces coelicolor A3(2), the holo-ACPs formed in vitro were fully functional in polyketide synthesis (Carreras $e t$ al., 1997). Moreover, co-expression of actinorhodin and griseusin ACPs with ACPS in E. coli gave high titres of active holo-ACPS (Cox et al., 1997), and E. coli ACPS efficiently modified post-translationally the apo-ACPs involved in biosynthesis of granaticin, frenolicin, oxytetracycline and tetracenomycin (Gehring et al., 1996). These results imply that E. coli ACPS has broad substrate specificity. However, it will not recognize the apo-forms of several PCP and ArCP domains, including the apo-PCP domain of E. coli EntF and the apo-ArCP domain of E. coli EntB (Lambalot et al., 1996; Gehring et al., 1996; Quadri et al., 1998a). Our evidence that an $S$. venezuelae ISP5230 mutant disrupted in jadM is unaffected in the production of chloramphenicol, an antibiotic now known to be biosynthesized via a nonribosomal peptide synthetase (J. Y. He, N. Magarvey, M. Piraee, K. A. Aidoo \& L. C. Vining, unpublished results) indicates that JadM is not required for this process, and could mean that it is not recognized by the PCP domain in the NRPS. There may be a separate PPTase in the $\mathrm{cml}$ cluster catalysing the conversion of apo-PCP to its holo-form. Since the jadM-disrupted mutants VS1075 and VS1076 grew normally on minimal agar, jadM is also not essential for fatty acid biosynthesis, and thus appears to be a jadomycin B pathway-specific PPTase.

Although this report is the first to describe the cloning and characterization from a streptomycete of a gene encoding a PPTase, more than 20 examples of PPTases, including ACPS, EntD and O195 of E. coli, Sfp of B. subtilis and Gsp of B. brevis, have been added to the group on the basis of sequence similarity since the superfamily was first recognized (Lambalot et al., 1996; Walsh et al., 1997). However, only a few have been extensively characterized. Among these are PPT1 from the type-II fatty acid synthase of Brevibacterium ammoniagenes (Stuible et al., 1997), PPT2, which activates mitochondrial ACP in Saccharomyces cerevisiae (Stuible et al., 1998), Lys5 from the lysine biosynthesis system in S. cerevisiae (Ehmann et al., 1999), MtaA from the polyketide synthase/polypeptide synthetase complex synthesizing mycothiazole in Stigmatella aurantiaca (Gaitatzis et al., 2001) and PptT, which is required in the assembly of mycobactin, the peptide-polyketide siderophore of Mycobacterium tuberculosis (Gehring et al., 1997; Quadri et al., 1998b). The crystal structure of Sfp has indicated regions likely to be involved in interactions with the substrate of this PCP (Reuter et al., 1999), and since most of these regions are highly conserved among PPTase family members, directed mutations may provide insights into substrate recognition and specificity by PCP, ACP and NRPS enzyme complexes. Already the crystallographic investigations have allowed a catalytic mechanism to be proposed (Parris et al., 2000).

\section{REFERENCES}

Black, T. A. \& Wolk, C. P. (1994). Analysis of a HetI mutation in Anabaena sp. strain PCC7120 implicates a secondary metabolite in the regulation of heterocyst spacing. J Bacteriol 176, 2282-2292.

Borchert, S., Stachelhaus, T. \& Marahiel, M. A. (1994). Induction of surfactin production in Bacillus subtilis by gsp, a gene located upstream of the gramicidin S operon in Bacillus brevis. J Bacteriol 176, 2458-2462.

Carreras, C. W., Gehring, A. M., Walsh, C. T. \& Khosla, C. (1997). Utilization of enzymatically phosphopantetheinylated acyl carrier proteins and acetyl-acyl carrier proteins by the actinorhodin polyketide synthase. Biochemistry 36, 11757-11761.

Chang, z. (1999). Genes for cysteine biosynthesis and metabolism in Streptomyces venezuelae ISP5230: cloning, sequencing, functional analysis and relevance to chloramphenicol biosynthesis. $\mathrm{PhD}$ thesis, Dalhousie University.

Cox, R. J., Hitchman, T. S., Byrom, K. J., Findlow, I. S., Tanner, J. A., Crosby, J. \& Simpson, T. J. (1997). Post-translational modification of heterologously expressed Streptomyces type-II polyketide synthase acyl carrier proteins. FEBS Lett 405, 267-272.

Doull, J. L., Vats, S., Chaliciopoulos, M., Stuttard, C., Wong, K. \& Vining, L. C. (1986). Conjugational fertility and location of chloramphenicol biosynthesis genes on the chromosomal linkage map of Streptomyces venezuelae. J Gen Microbiol 132, 1327-1338.

Doull, J. L., Ayer, S. W., Singh, A. K. \& Thibault, P. (1993). Production of a novel polyketide antibiotic, jadomycin B, by Streptomyces venezuelae following heat shock. J Antibiot 46, 849-871.

Doull, J. L., Singh, A. K., Hoare, M. \& Ayer, S. W. (1994). Conditions for the production of jadomycin B by Streptomyces venezuelae ISP5230: effects of heat shock, ethanol treatment and phage infection. J Ind Microbiol 13, 120-125.

Ehmann, E. E., Gehring, A. M. \& Walsh, C. T. (1999). Lysine biosynthesis in Saccharomyces cerevisiae: mechanism of $\alpha$ - 
aminoadipate reductase (Lys 2) involved in post-translational phosphopantetheinylation by Lys 5. Biochemistry 38, 6171-6177.

Facey, S. (1994). Cloning, sequencing and expression of a bromoperoxidase-catalase gene from Streptomyces venezuelae. $\mathrm{PhD}$ thesis, Hohenheim University.

Gaitatzis, N., Han, A., Muller, R. \& Beyer, S. (2001). The $m t a A$ gene of the myxothiazol biosynthetic gene cluster from Stigmatella aurantiaca DW4/3-1 encodes a phosphopantetheinyl transferase that activates polyketide synthases and polypeptide synthetases. J Biochem 129, 119-124.

Gehring, A. M., Lambalot, R. H., Vogel, K. W., Drueckhammer, D. G. \& Walsh, C. T. (1996). Ability of Streptomyces spp. acyl carrier proteins and coenzyme A analogs to serve as substrates in vitro for E. coli holo-ACP synthase. Chem Biol 4, 17-24.

Gehring, A. M., Bradley, K. A. \& Walsh, C. T. (1997). Enterobactin biosynthesis in Escherichia coli; isochorismate lyase (EntB) is a bifunctional enzyme that is phosphopante-theinylated by EntD and then acylated by EntE using ATP and 2,3-dihydroxybenzoate. Biochemistry 36, 8495-8503.

Gokhale, R. S., Tsuji, S. Y., Cane, D. E. \& Khosla, C. (1999). Dissection and exploiting intermodular communication in polyketide synthases. Science 284, 482-485.

Han, L., Yang, K., Ramalingam, E., Mosher, R. H. \& Vining, L. C. (1994). Cloning and characterization of polyketide synthase genes for jadomycin B biosynthesis in Streptomyces venezuelae ISP5230. Microbiology 140, 3379-3389.

Han, L., Yang, K., Kulowski, K., Wendt-Pienkowski, E., Hutchinson, C. R. \& Vining, L. C. (2000). An acyl-coenzyme A carboxylase-encoding gene associated with jadomycin biosynthesis in Streptomyces venezuelae ISP 5230. Microbiology 146, 903-910.

Hopwood, D. A. (1997). Genetic contributions to understanding polyketide synthases. Chem Rev 97, 2465-2497.

Hopwood, D. A., Bibb, M. J., Chater, K. F., Kieser, T., Bruton, C. J., Kieser, H. M., Lydiate, D. J., Smith, C. P., Ward, J. M. \& Schrempf, H. (1985). Genetic Manipulation of Streptomyces: a Laboratory Manual. Norwich: The John Innes Foundation.

Hopwood, D. A. \& Sherman, D. H. (1990). Molecular genetics of polyketides and its comparison to fatty acid biosynthesis. Annu Rev Genet 24, 37-66.

Hutchinson, C. R. (1995). Polyketide synthase gene manipulation: a structure-function approach in engineering novel antibiotics. Annu Rev Microbiol 49, 201-238.

Ishikawa, J. \& Hotta, K. (1999). FramePlot: a new implementation of the Frame analysis for predicting protein-coding regions in bacterial DNA with a high G + C content. FEMS Microbiology Lett 174, 252-253.

Kaster, K. R., Burgett, S. G., Nagarajah Rao, R. \& Ingolia, T. D. (1983). Analysis of a bacterial hygromycin $B$ resistance gene by transcriptional and translational fusions and by DNA sequencing. Nucleic Acids Res 11, 6895-6911.

Kieser, T., Bibb, M. J., Buttner, M. J., Chater, K. F. \& Hopwood, D. A. (2000). Practical Streptomyces Genetics. Norwich: The John Innes Foundation.

Kulowski, K., Wendt-Pienkowski, E., Han, L., Yang, K., Vining, L. C. \& Hutchinson, C. R. (1999). Functional characterization of the jadI gene as a cyclase forming angucyclinones. J Am Chem Soc 121, 1786-1794.

Laemmli, U. K. (1970). Cleavage of structural proteins during the assembly of the head of bacteriophage T4. Nature 227, 680-685.

Lambalot, R. H., Gehring, A. M., Flugel, R. S., Zuber, P., LaCelle, M., Marahiel, M. A., Reid, R., Khosla, C. \& Walsh, C. T. (1996). A new enzyme superfamily - the phospho-pantetheinyl transferases. Chem Biol 3, 923-936.

Larson, J. L. \& Hershberger, C. L. (1986). The minimal replicon of a streptomycete plasmid produces an ultrahigh level of plasmid DNA. Plasmid 15, 199-209.

Leder, P., Tiemeier, D. \& Enquist, L. (1977). EK2 derivatives of bacteriophage lambda useful in the cloning of DNA from higher organisms: The $\lambda \mathrm{gtWES}$ system. Science 196, 175-177.

McVey, J. (1998). Characterization of the downstream genes for jadomycin B biosynthesis in Streptomyces venezuelae ISP5230. MSc thesis, Dalhousie University.

Malik, V. S. \& Vining, L. C. (1970). Metabolism of chloramphenicol by the producing organism. Can J Microbiol 16, 173-179.

Maniatis, T., Fritsh, E. F. \& Sambrook, J. (1982). Molecular Cloning: a Laboratory Manual. Cold Spring Harbor, NY: Cold Spring Harbor Laboratory.

Mazodier, P., Peter, R. \& Thompson, C. (1989). Intergeneric conjugation between Escherichia coli and Streptomyces species. J Bacteriol 171, 3583-3585.

Meurer, G., Gerlitz, M., Wendt-Pienkowski, E., Vining, L. C., Rohr, J. \& Hutchinson, C. R. (1997). Iterative type II polyketide synthases, cyclases and keto-reductases exhibit context-dependent behavior in the biosynthesis of linear and angular decapolyketides. Chem Biol 4, 433-443.

Parris, K. D., Lin, L., Tam, A., Mathew, R., Hixon, J., Stahl, M., Fritz, C. C., Seehra, J. \& Somers, W. S. (2000). Crystal structures of substrate binding to Bacillus subtilis holo-(acyl carrier protein) synthase reveal a novel trimeric arrangement of molecules resulting in three active sites. Structure Fold Des 8, 883-895.

Quadri, L. E., Weinreb, P. H., Lei, M., Nakano, M. M., Zuber, P. \& Walsh, C. T. (1998a). Characterization of Sfp, a Bacillus subtilis phosphopantetheinyl transferase for peptidyl carrier protein domains in peptide synthetases. Biochemistry 37, 1585-1595.

Quadri, L. E., Sello, J., Keating, T. A., Weinreb, P. H. \& Walsh, C. T. (1998b). Identification of a Mycobacterium tuberculosis gene cluster encoding the biosynthetic enzymes for assembly of the virulence-conferring siderophore mycobactin. Chem Biol 5, 631-645.

Reuter, K., Mofid, M. R., Marahiel, M. A. \& Ficner, R. (1999). Crystal structure of the surfactin synthetase-activating enzyme Sfp: a prototype of the $4^{\prime}$-phosphopantetheinyl transferase superfamily. EMBO J 18, 6823-6831.

Sambrook, J., Fritsch, E. F. \& Maniatis, T. (1989). Molecular Cloning: a Laboratory Manual. Cold Spring Harbor, NY : Cold Spring Harbor Laboratory.

Sanger, F., Nicklen, S. \& Coulson, A. R. (1977). DNA sequencing with chain-terminating inhibitors. Proc Natl Acad Sci US A 74, 5463-5467.

Silakowski, B., Schairer, H. U., Ehret, H. \& 8 other authors (1999). New lessons for combinatorial biosynthesis from myxobacteria: the myxothiazol biosynthetic gene cluster of Stigmatella aurantiaca DW4/3-1. J Biol Chem 274, 37391-37399.

Stuible, H.-P., Meier, S. \& Schweizer, E. (1997). Identification, isolation and biochemical characterization of a phosphopantetheine:protein transferase that activates the two type-I fatty acid synthases of Brevibacterium ammoniagenes. Eur J Biochem 248, 481-487.

Stuible, H.-P., Meier, S., Wager, C., Hannappel, E. \& Schweizer, E. (1998). A novel phosphopantetheine:protein transferase activating yeast mitochondrial acyl carrier protein. J Biol Chem 273, 22334-22339.

Stuttard, C. (1982). Temperate phages of Streptomyces 
venezuelae: lysogeny and host specificity shown by SV1 and SV2. J Gen Microbiol 128, 115-121.

Thompson, J. D., Higgins, D. G. \& Gibson, T. J. (1994). CLUSTAL W : improving the sensitivity of progressive multiple sequence alignment through sequence weighting, position-specific gap penalties and weight matrix choice. Nucleic Acids Res 22, 4673-4680.

Walsh, C. T, Gehring, A. M., Weinreb, P. H., Quadri, L. E. \& Flugel, R. S. (1997). Post-translational modification of polyketide and nonribosomal peptide synthases. Curr Opin Chem Biol 1, 309-319.

Yamamoto, K. R., Alberts, B. M., Benzinger, R., Lawhorne, L. \& Treiber, G. (1970). Rapid bacteriophage sedimentation in the presence of polyethylene glycol and its application to large-scale virus purification. Virology 40, 734-744.

Yang, K., Han, L. \& Vining, L. C. (1995). Regulation of jadomycin B biosynthesis in Streptomyces venezuelae ISP5230: involvement of a repressor gene, jadR2. J Bacteriol 177, 6111-6117.

Yang, K., Han, L., Ayer, S. W. \& Vining, L. C. (1996). Accumulation of the angucycline antibiotic rabelomycin after disruption of an oxygenase gene in the jadomycin B biosynthetic gene cluster of Streptomyces venezuelae. Microbiology 142, 123-132.

Received 28 November 2000; revised 9 February 2001; accepted 21 February 2001. 